\title{
Salt tolerance of cowpea genotypes during seed germination and seedling growth
}

\author{
Md. Mozahidul Islam, ${ }^{\bowtie}$ Md. Sabibul Haque and AKM Golam Sarwar
}

Department of Crop Botany, Bangladesh Agricultural University, Mymensingh 2202, Bangladesh

\begin{tabular}{|c|c|}
\hline ARTICLE INFO OPENOA & \\
\hline $\begin{array}{l}\text { ceived : } 31 \text { January } 2019 \\
\text { cepted : 05 March } 2019 \\
\text { lished: } 31 \text { March } 2019\end{array}$ & \multirow{3}{*}{$\begin{array}{l}\text { Cowpea (Vigna unguiculata (L.) Walp.) is one of the most important grain legumes worldwide and its } \\
\text { production is affected by increasing soil salinity due to global climate change. An experiment was } \\
\text { conducted at the Plant Physiology Laboratory of the Department of Crop Botany, Bangladesh Agricultural } \\
\text { University, Mymensingh to evaluate the germination capability of seven cowpea genotypes under salt } \\
\text { stress. The germination test was carried out in Petri dishes following two factorial CRD with three } \\
\text { replications. Seven cowpea genotypes viz, Red Pine, Green Super, Hai Jiang San Hao, Kegornatki, } \\
\text { Kegornatki Green, Kegornatki HYV \& Kegornatki Red; and three salt levels viz, 0, } 6 \text { \& } 12 \mathrm{dSm}^{-1} \text {, were } \\
\text { used as experimental treatments. The germination percentage (GP), mean germination time (MGT), } \\
\text { radicle and plumule length, radicle and plumule fresh and dry weight and different stress tolerance indices } \\
\text { were recorded to screen the genotypes for salt tolerance. The study highlighted that salt concentrations } \\
\text { drastically reduced seed germination and significantly delayed the process in all genotypes. The GP, } \\
\text { length and biomass of radicle and plumule and salt tolerance indices were significantly decreased while } \\
\text { the MGT was significantly increased with increasing salt stress in all cowpea genotypes. A significant } \\
\text { variation among the genotypes in response to salt stress was also observed. Among the seven cowpea } \\
\text { genotypes, Hai Jiang San Hao and Green Super showed higher salt tolerance in comparison to the other } \\
\text { genotypes based on the measured traits; these genotypes can be used for further breeding program and/or } \\
\text { cultivation in coastal saline prone areas with further investigation. }\end{array}$} \\
\hline $\begin{array}{l}\text { mination, plant } \\
\text { ss tolerance index }\end{array}$ & \\
\hline & \\
\hline
\end{tabular}

Copyright:

(c) (i)

(O2019 by authors and BAURES. This work is licensed under the Creative Commons Attribution International License (CC By 4.0).

\section{Introduction}

Soil salinity is a serious threat to crop production, biodiversity, food and nutritional security. Intrusion of saline water into cultivable lands due to sea level rise as a consequence of global warming exacerbates soil salinity in the coastal areas of Bangladesh. Salinity affected area in Bangladesh has increased from 8,330 square $\mathrm{km}$ in 1973 to 10,560 square $\mathrm{km}$ in 2009 (SRDI, 2010). The coast of Bangladesh consists of 19 districts, covers $32 \%$ of the country and accommodates more than 35 million people (Huq and Rabbani, 2011). Ecology of the coastal region especially in the south-west region is greatly concerned with salinity. Salinity is a great constraint to growing crops, especially in rabi season (dry months) when soil salinity arises and reaches to the peak in March-April before monsoon starts (Haque et al., 2008). Most crop plants are susceptible to saline soil and cowpea (Vigna unguiculata (L.) Walp.) is considered as highly susceptible to salt stress (McKenzie, 1988). Cowpea is an important seed legume crop in Bangladesh. It is cultivated to obtain seeds and pods for human consumption and as a source of green manure and organic material. Salinity stress reduced the speed and percentage germination of seed, decreased in shoot length, fresh and dry weights of shoots and roots of plants (Fateme et al., 2010). Presence of salt at concentrations higher than $50 \mathrm{mM} \mathrm{NaCl}$ affect the germination, seedlings growth and total protein synthesis in cowpea cultivars (Dantas et al., 2005). Soil salinity may affect the germination of seeds either by creating a lower osmotic potential external to the seed preventing water uptake or through the toxic effects of $\mathrm{Na}^{+}$and $\mathrm{Cl}^{-}$ ions on the germinating seeds (Khajeh-Hosseini et al., 2003). Salt stress can also lead to oxidative stress due to increased production of reactive oxygen species (ROS), such as singlet oxygen $\left({ }^{1} \mathrm{O}_{2}\right)$, superoxide anion $\left(\mathrm{O}_{2}{ }^{-}\right)$, hydrogen peroxide $\left(\mathrm{H}_{2} \mathrm{O}_{2}\right)$ and hydroxyl radical (Bray et al., 2000).

Salt tolerance is the ability of plants to grow and complete their life cycle on a substrate that contains high concentrations of soluble salt. Various strategies can be adopted to cope with salinity stress such as screening and selection, conventional breeding and use of transgenics on the basis of morphological, physiological and biochemical traits. Dasgan et al. (2002) suggested the screening at the seedling stage is not only less laborious, less time consuming and less expensive, but also has a high reliability. While establishing appropriate salinity screening techniques, it is also important to understand which of the physiological or biochemical processes is more sensitive to salt stress that can be used as effective selection criterion (Ashraf and Harris, 2004). 
Munns et al. (2002) suggested that screening for a trait associated with a specific mechanism of salt tolerance is a preferable method. Therefore, the objective of this study was to evaluate the influence of salt stress on germination and seedling growth of seven cowpea genotypes with a view to a better understanding of the mechanisms and capability of salt tolerance in these genotypes.

\section{Materials and Methods}

The experiment was conducted in the Plant Physiology laboratory, Department of Crop Botany, Bangladesh Agricultural University in 2017. The seeds of seven cowpea genotypes viz. Red Pine, Green Super, Hai Jiang San Hao, Kegornatki, Kegornatki Green, Kegornatki HYV and Kegornatki Red were collected from different seed companies in Bangladesh and China. A two factorial experiment was set following completely randomized design (CRD) with three replications. The experimental factors were i) cowpea genotypes (seven) and ii) salt stress (three levels; 0,6 and $12 \mathrm{dSm}^{-1}$ ). The seven genotypes were randomly assigned to seven Petri dishes $(9 \mathrm{~cm}$ diameter of which each Petri dish contained 10 seeds of each genotype following three replicates). Therefore, a total of 63 Petri dishes were required for the experiment. Three salt treatments i.e. 0 (control), 6 and $12 \mathrm{dSm}^{-1}$ were obtained by dissolving $\mathrm{NaCl}$ in the solution until the treatment level reached to the desired EC. An EC meter was used to check the desired EC regularly. The control i.e. $0 \mathrm{dSm}^{-1}$ was maintained using distilled water only. The cowpea seeds were sterilized with 5\% sodium hypochlorite for $30 \mathrm{~min}$ and washed thoroughly with distilled water. The seeds were then soaked in water and imbibed for $24 \mathrm{~h}$ and then placed in Petri dishes containing filter paper to allow them for germination. In control, $4 \mathrm{~mL}$ of distilled water was added to the Petri dish. Filter papers were moistened with $4 \mathrm{~mL}$ of respective salt solutions to develop the respective level of salt treatments $\left(6 \mathrm{dSm}^{-1}\right.$ and 12 $\mathrm{dSm}^{-1}$ ). The cowpea seeds were allowed to germinate at around $25^{\circ} \mathrm{C}$ room temperature and kept them for eight days for observation. The number of germinated seeds ( 2 $\mathrm{mm}$ radicle length) was counted every day. The final count was done on day eight and germination percentage (GP) was calculated using the following formulae.

Germination Percentage (GP) $=$

Total no. of seeds germinated at day $8 \times 100$

Total no. of seeds taken for germination

The mean germination time (MGT) was calculated using the daily counts, according to the following equation described by Moradi et al. (2008).

$M G T=\Sigma n D / \Sigma N$

Where, $\mathrm{n}$ is the number of newly germinated seeds at day $\mathrm{D} ; \mathrm{D}=$ days from the beginning of the germination test; $\mathrm{N}=$ number of all germinated seeds (final germination).
Plumule Length (PL) was measured from shoot base to the tip of the longest leaf and Radicle Length (RL) was measured from root base to the root tip. Seedling fresh weight was recorded immediately after the harvest at day eight. The promptness index (PI) and different physiological indices like Germination Stress Tolerance index (GSTI), Root Length Stress Tolerance Index (RLSI), Plant Height Stress Tolerance Index (PHSI), Shoot Fresh Weight Stress Tolerance Index (SFSI), Root Fresh Weight Stress Tolerance Index (RFSI), Shoot Dry Weight Stress Tolerance Index (SDSI) and Root Dry Weight Stress Tolerance Index (RDSI) were calculated using the following formula described by Ashraf and Harris (2004).

$\mathrm{PI}=\mathrm{nd} 1(1.00)+\mathrm{nd} 2(0.75)+\mathrm{nd} 3(0.50)+\mathrm{nd} 4(0.25)$

Where, nd1, nd2, nd3 and nd4 $=$ Number of seeds germinated on the 2nd, 4th, 6th and 8th day, respectively.

GSTI $=($ PI of stressed seeds $/$ PI of control seeds $)$ X 100

PHSI $=($ Plant height of stressed plants / plant height of control plants) X 100

RLSI $=$ (Radicle length of stressed plants / radicle length of control plants) X 100

SFSI $=($ Shoot fresh weight of stressed plants / shoot fresh weight of control plants) $X 100$

RFSI $=($ Root fresh weight of stressed plants / root fresh weight of control plants) X 100

SDSI $=($ Shoot dry weight of stressed plants / shoot dry weight of control plants) X 100

RDSI $=($ Root dry weight of stressed plants / root dry weight of control plants) X 100

The statistical software ' $R$ ' was used to evaluate the variations of parameters among the treatments and genotypes.

\section{Results}

Germination percentage (GP) showed significant differences among the genotypes and the salt treatments (Fig. 1). Results revealed that germination percentage was decreased with the increase of salinity. The highest GP was recorded in Green Super and Hai Jiang San Hao and the lowest was found in Red Pine and Kegornatki Green in control condition. But in both 6 and $12 \mathrm{dSm}^{-1}$ treatments, the highest GP was recorded in Hai Jiang San Hao and lowest was recorded in Kegornatki Green (Fig. $1 \&$ 2). There were no significant differences in GP between 0 and $6 \mathrm{dSm}^{-1}$ in all genotypes except Red Pine (Fig. 1). The mean germination time (MGT) was significantly increased under salt treatments compared to control in all genotypes (Fig. 3). The lower MGT was found in Hai Jiang San Hao followed by Kegornatki Red and higher was observed in Red Pine at $6 \mathrm{dSm}^{-1}$ salt treatment (Fig. 3). At $12 \mathrm{dSm}^{-1}$ treatment, the MGT was also lowest in Hai Jiang San Hao and highest in Red Pine and Kegornatki in comparison to other genotypes (Fig. 3). An increasing trend of MGT was found with the increase of salt concentrations in all genotypes except Red Pine and Kegornatki Green. 

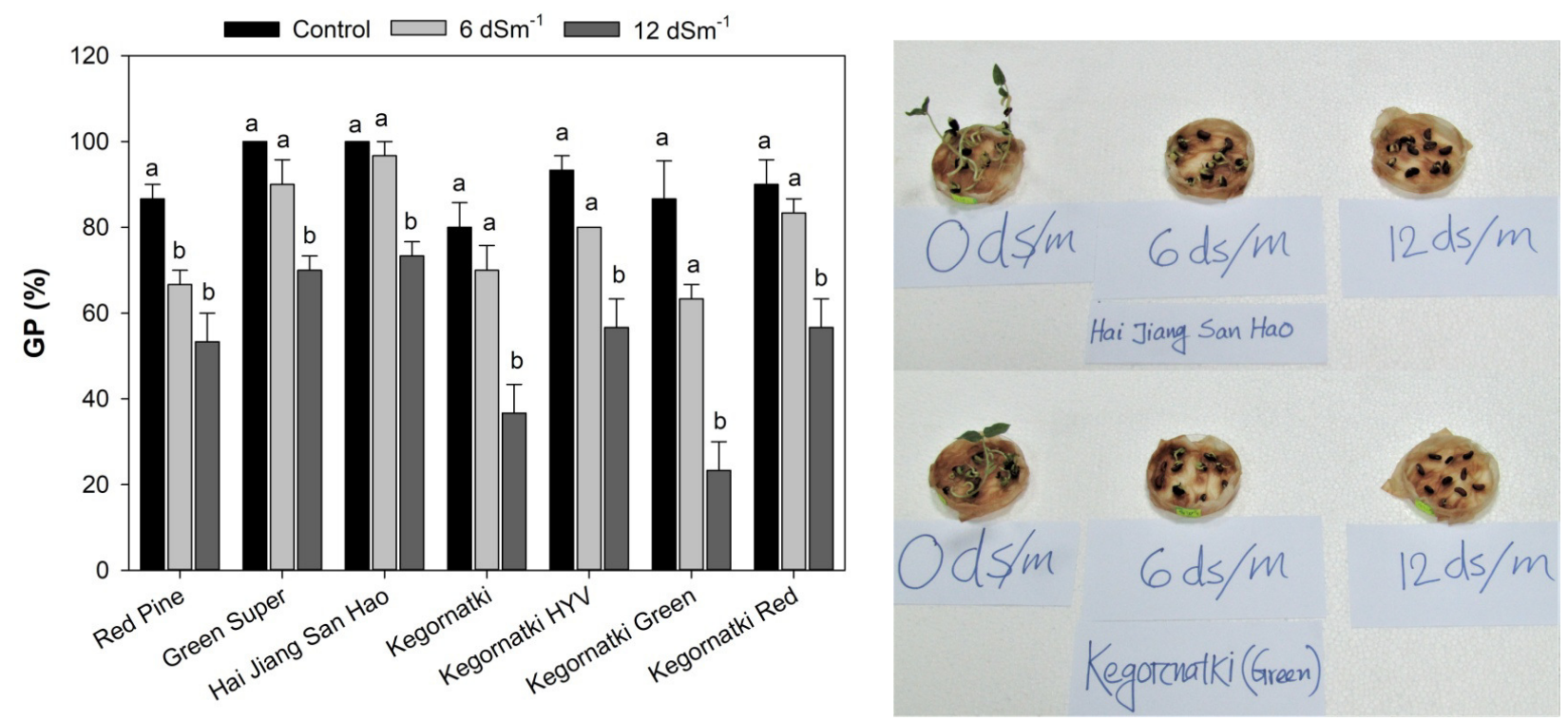

\section{Genotypes}

Fig. 1. Germination Percentage (GP, \%) of seven cowpea genotypes grown under three salt levels $(0,6$ and $12 \mathrm{dSm}$ $\left.{ }^{1}\right)$. Vertical bars are SEM $(n=3)$. Treatment means with different letters within each genotype are significantly different at $5 \%$ level of probability.

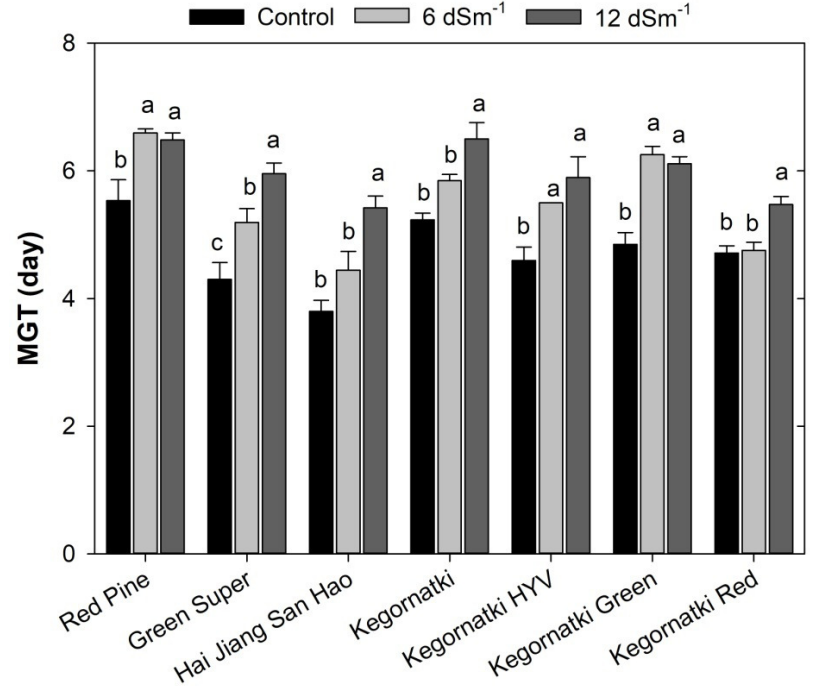

Genotypes

Fig. 3. Mean Germination Time (MGT, day) of seven cowpea genotypes grown under three salt levels $(0,6$ and 12 $\left.\mathrm{dSm}^{-1}\right)$. Vertical bars are SEM $(\mathrm{n}=3)$. Treatment means with different letters within each genotype are significantly different at $5 \%$ level of probability

The GSTI values at both 0 and $6 \mathrm{dSm}^{-1}$ were significantly differed among the genotypes (Fig. 4). At 6 $\mathrm{dSm}^{-1}$, the GSTI was greater in Green Super followed by Hai Jiang San Hao and lower in Kegornatki Green in comparison to other genotypes (Fig. 4A). At higher salt level $\left(12 \mathrm{dSm}^{-1}\right)$, the maximum GSTI value was recorded in Hai Jiang San Hao followed by Green Super compared to the other genotypes (Fig. 4B). The genotypes Kegornatki Green and Kegornatki showed lowest GSTI values at $12 \mathrm{dSm}^{-1}$ salt levels (Fig. 4B). According to the average GSTI values $\left(6\right.$ and $12 \mathrm{dSm}^{-1}$ ), the salt tolerant genotypes can be ranked as Hai Jian San Hao > Green Super > Kegornatki Red > Kegornatki Green $>$ Red Pine $>$ Kegornatki $>$ Kegornatki HYV. The different levels of salinity also significantly affected the radicle and plumule length in all genotypes (Fig. 5A-B). At $6 \mathrm{dSm}^{-1}$ salt level, the genotypes Hai Jiang San Hao and Kegornatki Red showed the highest radicle and plumule length whereas, the genotype Kegornatki Green had the lowest radicle and plumule growth (Fig. 5A-B). The radicle and plumule length of all the genotypes were highly affected by $12 \mathrm{dSm}^{-1}$ level of salt stress. The Hai Jiang San Hao and Kegornatki Red genotypes performed better in relation to radicle and plumule length than the other genotypes (Fig. 5). The other physiological indices significantly varied among the seven genotypes. In 6 $\mathrm{dSm}^{-1}$, all physiological indices (PHSI, RLSI, SFSI, RFSI, SDSI and RDSI) were highest in Hai Jiang San Hao (Table 1). The genotype Kegornatki Green showed lowest PHSI, SFSI, SDSI and RDSI but the lowest RLSI, RFSI were recorded in Kegornatki Red and Kegornatki, respectively (Table 1). The maximum PHSI, RLSI, SFSI, SDSI and RDSI values were recorded in Hai Jiang San Hao whereas, the RFSI value was highest in Green Super at $12 \mathrm{dSm}^{-1}$ (Table 1). 


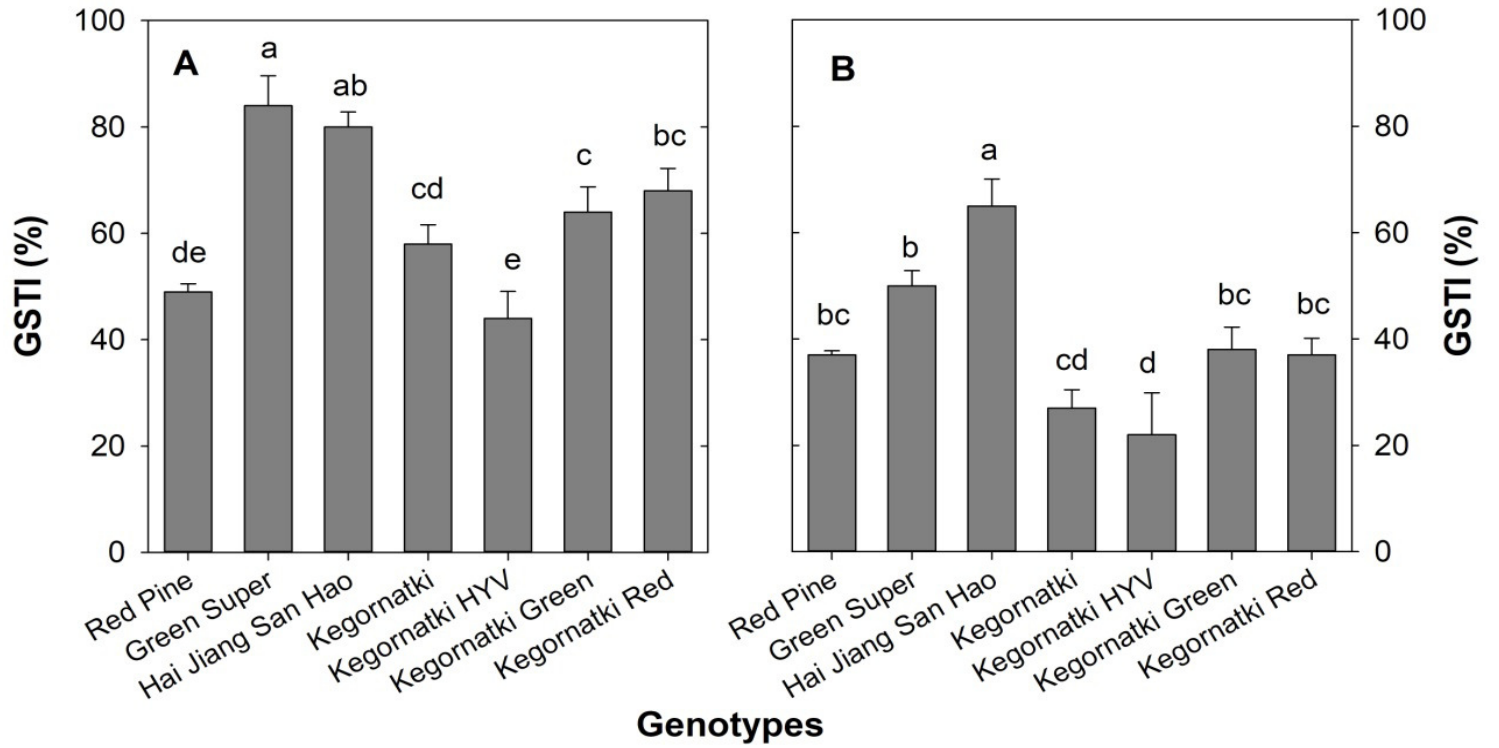

Fig. 4. Germination Stress Tolerance Index (GSTI, \%) of seven cowpea genotypes grown under $6 \mathrm{dSm}^{-1}$ (A) and $12 \mathrm{dSm}^{-1}$ (B) salt levels. Vertical bars are SEM $(n=3)$. Treatment means with different letters within the genotypes are significantly different at $5 \%$ level of probability.

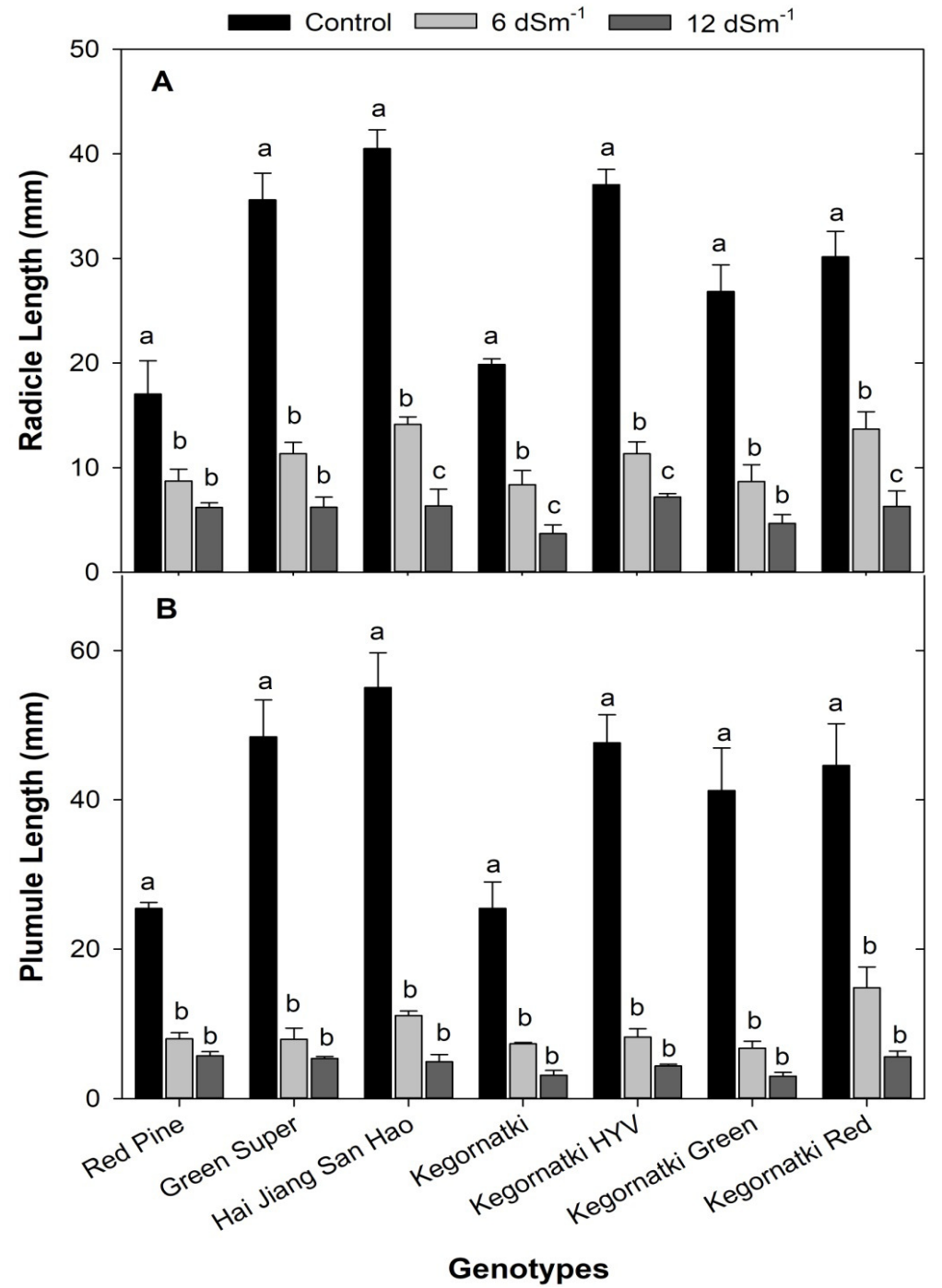

Fig. 5. Radicle (A) and plumule (B) length (mm) of seven cowpea genotypes grown under three salt levels $\left(0,6\right.$ and $\left.12 \mathrm{dSm}^{-1}\right)$. Vertical bars are SEM $(n=3)$. Treatment means with different letters within each genotype are significantly different at $5 \%$ level of probability. 
Table 1. Physiological stress tolerance indices of seven cowpea genotypes grown under different salt treatments

\begin{tabular}{|c|c|c|c|c|c|c|c|c|c|c|c|c|}
\hline & \multicolumn{2}{|c|}{ PHSI } & \multicolumn{2}{|c|}{ RLSI } & \multicolumn{2}{|c|}{ SFSI } & \multicolumn{2}{|c|}{ RFSI } & \multicolumn{2}{|c|}{ SDSI } & \multicolumn{2}{|c|}{ RDSI } \\
\hline & $\begin{array}{c}6 \\
\mathrm{dSm}^{-1}\end{array}$ & $\begin{array}{c}12 \\
\mathrm{dSm}^{-1}\end{array}$ & $\begin{array}{c}6 \\
\mathrm{dSm}^{-1}\end{array}$ & $\begin{array}{c}12 \\
\mathrm{dSm}^{-1}\end{array}$ & $\begin{array}{c}6 \\
\mathrm{dSm}^{-1}\end{array}$ & $\begin{array}{c}12 \\
\mathrm{dSm}^{-1}\end{array}$ & $\begin{array}{c}6 \\
\mathrm{dSm}^{-1}\end{array}$ & $\begin{array}{c}12 \\
\mathrm{dSm}^{-1}\end{array}$ & $\begin{array}{c}6 \\
\mathrm{dSm}^{-1}\end{array}$ & $\begin{array}{c}12 \\
\mathrm{dSm}^{-1}\end{array}$ & $\begin{array}{c}6 \\
\mathrm{dSm}^{-1}\end{array}$ & $\begin{array}{c}12 \\
\mathrm{dSm}^{-1}\end{array}$ \\
\hline Red Pine & $19 \pm 5 \mathrm{c}$ & $11 \pm 5 b$ & $26 \pm 9 \mathrm{bc}$ & $18 \pm 4 b$ & $72 \pm 8 \mathrm{c}$ & $47 \pm 1 d$ & $72 \pm 5 \mathrm{c}$ & $48 \pm 1 \mathrm{~d}$ & $79 \pm 4 c$ & $62 \pm 6 \mathrm{c}$ & $86 \pm 5 a$ & $67 \pm 7 \mathrm{ab}$ \\
\hline Green Super & $34 \pm 5 a$ & $13 \pm 2 b$ & $34 \pm 5 \mathrm{ab}$ & $23 \pm 4 b$ & $82 \pm 2 b$ & $64 \pm 3 a b$ & $84 \pm 7 b$ & $67 \pm 4 a$ & $91 \pm 3 \mathrm{ab}$ & $77 \pm 2 \mathrm{a}$ & $72 \pm 1 \mathrm{~b}$ & $77 \pm 3 \mathrm{a}$ \\
\hline Hai Jiang San Hao & $36 \pm 2 \mathrm{a}$ & $26 \pm 4 \mathrm{a}$ & $39 \pm 3 \mathrm{a}$ & $45 \pm 4 \mathrm{a}$ & $90 \pm 3 \mathrm{a}$ & $67 \pm 2 \mathrm{a}$ & $92 \pm 2 \mathrm{a}$ & $64 \pm 1 \mathrm{ab}$ & $92 \pm 3 \mathrm{a}$ & $82 \pm 3 a$ & $91 \pm 7 \mathrm{a}$ & $79 \pm 13 \mathrm{a}$ \\
\hline Kegornatki & $17 \pm 7 \mathrm{c}$ & $7 \pm 1 b$ & $25 \pm 6 \mathrm{bc}$ & $16 \pm 5 b$ & $72 \pm 2 c$ & $58 \pm 1 \mathrm{bc}$ & $59 \pm 1 \mathrm{~d}$ & $55 \pm 2 c$ & $83 \pm 4$ bc & $61 \pm 4 c$ & $82 \pm 5 a$ & $60 \pm 4 b$ \\
\hline Kegornatki Green & $16 \pm 1 \mathrm{c}$ & $12 \pm 6 b$ & $30 \pm 5 a-c$ & $17 \pm 3 b$ & $58 \pm 1 d$ & $56 \pm 1 \mathrm{c}$ & $72 \pm 3 c$ & $53 \pm 10 \mathrm{~cd}$ & $70 \pm 2 d$ & $55 \pm 3 d$ & $65 \pm 2 b$ & $65 \pm 5 \mathrm{ab}$ \\
\hline Kegornatki HYV & $30 \pm 5 \mathrm{ab}$ & $13 \pm 6 b$ & $31 \pm 4 \mathrm{a}-\mathrm{c}$ & $22 \pm 7 b$ & $76 \pm 3 \mathrm{bc}$ & $59 \pm 7$ bc & $77 \pm 4 c$ & $58 \pm 4 \mathrm{bc}$ & $90 \pm 1 \mathrm{ab}$ & $75 \pm 3 \mathrm{ab}$ & $86 \pm 8 \mathrm{a}$ & $75 \pm 10 \mathrm{ab}$ \\
\hline Kegornatki Red & $23 \pm 10 b c$ & $9 \pm 3 b$ & $23 \pm 3 c$ & $19 \pm 8 b$ & $74 \pm 1 \mathrm{c}$ & $55 \pm 4 \mathrm{c}$ & $72 \pm 3 c$ & $58 \pm 2 \mathrm{bc}$ & $88 \pm 9 \mathrm{ab}$ & $71 \pm 6 b$ & $86 \pm 3 \mathrm{a}$ & $72 \pm 8 \mathrm{ab}$ \\
\hline
\end{tabular}

Values are treatment means \pm SD. In a column, treatment means with different letters are statistically significant at $5 \%$ level of probability. PHSI $=$ Plant Height Stress Tolerance Index, RLSI $=$ Root Length Stress Tolerance Index, SFSI $=$ Shoot Fresh Weight Stress Tolerance Index, RFSI $=$ Root Fresh Weight Stress Tolerance Index, SDSI $=$ Shoot Dry Weight Stress Tolerance Index and RDSI $=$ Root Dry Weight Stress Tolerance Index.

\section{Discussion}

Seed germination or seedling establishment is a critical and fundamental process in plants growth cycle especially during the abiotic stress conditions (Bohnert et al., 1995). For this purpose, a germination test was conducted with seven cowpea genotypes seeds under three salinity levels $\left(0,6\right.$ and $\left.12 \mathrm{dSm}^{-1}\right)$ in order to identify contrasted genotypes, i.e. salt tolerant versus salt sensitive. This study revealed that salt stress induced lower germination percentage, germination stress tolerance index (GSTI) and increased time for germination (MGT) of seven cowpea genotypes. The experiment also showed significant variation in the capability of salt tolerance among the cultivars. This means there are genetically differences among cultivars with respect to tolerance to salt stress. Similar findings were highlighted in many studies (Thiam et al., 2013; Abdel-Haleem and El-Shaieny, 2015; Tsague et al., 2017). The GP of all cowpea genotypes ranged from 23 to $100 \%$, whereas, the MGT ranged from 4 to 7 days, depending on treatments. The higher GP and lower MGT of all genotypes in the control $\left(0 \mathrm{dSm}^{-1}\right)$ were due to the lack of salt in the medium. Increasing salinity decreased the GP in all genotypes but some genotypes were more tolerant than the others. In addition to reducing the GP in sensitive genotypes, salt stress also delayed germination and slows its speed. The reduced GP and germination speed could be due to the alteration of enzymes and hormones contained in the seeds (Khan and Rezvi, 1994) or reduction in imbibitions of water by seeds because of lower osmotic potential of germination media (Khan and Weber, 2008) or due to the toxicity of salt constituents or ions to the embryo (Zhu, 2001).

Many studies indicated that the genotypes which maintained higher germination under salt stress produced higher biomass and yield (Krishnamurthy et al., 2007; Parihar et al., 2015; Ilori, 2017). However, in contrast, salt tolerant genotypes can be identified on the basis of germination stress tolerance index (GSTI) because during germination, seed vigor and seed storage conditions also affect. Results revealed that in both salt conditions the genotypes Hai Jiang San Hao and Green Super showed better salt tolerance having higher GSTI values in comparison to the other genotypes. Based on the average GSTI of both salt treatments, these two genotypes ranked first and second followed by Green Super (third) in relation to salt tolerance. Kegornatki HYV and Kegornatki genotypes showed salt susceptible according to this criterion. Lauchli and Grattan (2007) described that the germination rates and percentage of germinated seeds at a particular time vary considerably among species and cultivars. A number of studies have shown the genetic variability of cowpea genotypes to salt tolerance (Praxedes et al., 2014; Abdel-Haleem and El-Shaieny, 2015; da Silva Sa et al., 2016; Tsague et al., 2017).

Salt stress also significantly reduced the radicle and plumule length, plant height and biomass in all seven cowpea genotypes in this study. The genotypic variation was examined by estimating the physiological indices using these growth parameters. All physiological indices (PHSI, RLSI, SFSI, RFSI, SDSI and RDSI) were decreased due to salinity showing that the growth was significantly affected by salt stress. The genotypes Hai Jiang San Hao and Green Super had the higher tolerance indices reflecting in greater salt tolerance. The inhibition of growth in the genotypes might be due to two reasons. First, the reduction of plants ability to take up water which leads to slower growth i.e. osmotic or water deficit effect of salinity. Second, it may enter the transpiration stream and eventually injure cells in the transpiring leaves, further reducing growth i.e. saltspecific or ion-excess of salinity (Munns, 1993, 2005). A number of studies have shown a significant reduction in seed germination and seedling growth of different crops under salt stress and also a large genotypic variation in response to salt stress was widely observed (Farooq et al., 2015; Parihar et al., 2015).

\section{Conclusion}

The study revealed a considerable variation in salt tolerance among the studied cowpea genotypes at the germination level. The GP, radicle and plumule length, plant biomass and different salt tolerant indices (GSTI, PHSI, RLSI, SFSI, RFSI, SDSI and RDSI) were decreased significantly with increasing salinity while the 
mean germination time (MGT) increased significantly with the increase of salinity. The results indicated that under all evaluated condition, Hai Jiang San Hao and Green Super genotypes were found to be most tolerant to salt stress than other genotypes. The variability of genotypes to salt stress can be used later in breeding programs associated with the identification of molecular markers linked to salt tolerance in cowpea. Further study will be needed to assess whether these genotypes characterized at the germination level as tolerant based on their responses to salt stress maintain their tolerance at other growth and developmental stages.

\section{References}

Abdel-Haleem and El-Shaieny, A.H. 2015. Seed germination percentage and early seedling establishment of five Vigna unguiculata (L.) Walp. genotypes under salt stress. European Journal of Experimental Biology, 5: 22-32.

Ashraf, M. and Harris, J.C. 2004. Potential biochemical indicators of salinity tolerance in plants. Plant Science, 166: 3-16. https://doi.org/10.1016/j.plantsci.2003.10.024

Bohnert, H.J., Nelson, D.E. and Jensen, R.G. 1995. Adaptations to environmental stresses. Plant Cell, 7: 1099-1111. https://doi.org/10.1105/tpc.7.7.1099 PMid:12242400 PMCid:PMC160917

Bray, E.A., Bailey-Serres, J. and Weretilnyk, E. 2000. Responses to abiotic stresses. In Buchanan, B.B., Gruissem, W. and Jones, R.L. (eds). Biochemistry and Molecular Biology of Plants. pp. 1158-1203. American Society of Plant Physiologists, Rockville.

da Silva Sá, F.V., de Lima, G.S., dos Santos, J.B., Gheyi, H.R., dos Anjos Soares, L.A., Cavalcante, L.F., de Paiva, E.P. and de Pádua Souza, L. 2016. Growth and physiological aspects of bell pepper (Capsicum аппиит) under saline stress and exogenous application of proline. African Journal of Biotechnology, 15: 1970-1976. DOI: 10.5897/AJB2016. 15441

Dantas, B.F., de Sa Ribeiro, L. and Aragao, C.A. 2005. Physiological response of cowpea seeds to salinity stress. Revista Brasileira Sementes, 27: 144-148. https://doi.org/10.1590/S0101-31222005000100018

Dasgan, H.Y., Aktas, H., Abak, K. and Cakmar, I. 2002. Determination of screening techniques to salinity tolerance in tomatoes and investigation and investigation of genotypes response. Plant Science, 163: 695-703. https://doi.org/10.1016/S0168-9452(02)00091-2

Farooq, M., Hussain, M., Wakeel, A. and Siddique, K.H.M. 2015. Salt stress in maize: effects, resistance mechanisms and management - a review. Agronomy of Sustainable Development, 35: 461-481.

https://doi.org/10.1007/s13593-015-0287-0

Fateme, K., Rayhaneh, A., Akbar, M. and Giti, E. 2010. Effect of hydro and osmopriming in two commercial chickpea (Cicer arietinum L.) cultivars on germination, growth parameters and nodules number in salt stress condition. Iran Journal of Plant Biology, 2: 71-86.

Haque, M.A., Jharna, D.E., Hoque, M.F., Uddin, M.N. and Saleque, M.A. 2008. Soil solution electrical conductivity and basic cations composition in the rhizosphere of lowland rice in coastal soils. Bangladesh Journal of Agricultural Research, 33: $243-250$.

Huq, S. and Rabbani, G. 2011. Climate change and Bangladesh: Policy and institutional development to reduce vulnerability. Journal of Bangladesh Studies, 13: 1-10.

Ilori, O.J. 2017. $\mathrm{NaCl}$ salinity - induced changes on the germination and growth of the Vigna unguiculata (L.) Walp.
International Journal of Advanced Research in Science, Engineering and Technology, 4: 4381-4387.

Khajeh-Hosseini, M., Powell, A.A. and Bimgham, I.J. 2003. The interaction between salinity stress and seed vigor during germination of soybean seeds. Seed Science and Technology, 31: 715-725.

https://doi.org/10.15258/sst.2003.31.3.20

Khan, M.A. and Rizvi, Y. 1994. Effect of salinity, temperature and growth regulators on the germination and early seedling growth of Atriplex griffithii var. Stocksii. Canadian Journal of Botany, 72: 475-479. https://doi.org/10.1139/b94-063

Khan, M.A. and Weber, D.J. 2008. Ecophysiology of High Salinity Tolerant Plants. 1st ed., Springer, Amsterdam.

Krishnamurthy, L., Serraj, R., Hash, C.T., Abdullah, J. Dakheel and Reddy, B.V.S. 2007. Screening sorghum genotypes for salinity tolerant biomass production. Euphytica, 156:15-24. https://doi.org/10.1007/s10681-006-9343-9

Lauchli, A. and Grattan S.R. 2007. Plant growth and development under salinity stress. M.A. Jenks et al. (eds.). Advances in Molecular Breeding Toward Drought and Salt Tolerant Crops. Springer Publications, pp1-32.

McKenzie. 1988. Tolerance of plants to soil salinity. In Proceedings of Dryland Salinity Control Workshop. pp. 246-251. Calgary, $\mathrm{AB}$.

Moradi, D.P., Sharif-Zadeh, F. and Janmohammadi, M. 2008. Influence of priming technique on seed germination behavior of maize inbreed lines (Zea mays L.). Journal of Agricultural and Biological Sciences, 3: 22-25.

Munns, R. 1993. Physiological processes limiting plant growth in saline soils: some dogmas and hypotheses. Plant Cell \& Environment, 16: 1524. https://doi.org/10.1111/j.1365-3040.1993.tb00840.x

Munns, R. 2005 Genes and salt tolerance: bringing them together. New Phytologist, 167: 645-663. https://doi.org/10.1111/j.1469-8137.2005.01487.x

Munns, R., Husain, S., Rivelli, A.R., James, R.A., Condon, A.G., Lindsay, M.P., Lagudah, E.S., Schachtman, D.P. and Hare, R.A. 2002. Avenues for increasing salt tolerance of crops, and the role of physiologically based selection traits. Plant and Soil, 247: 93-105. https://doi.org/10.1023/A:1021119414799

Parihar, P., Singh, S., Singh, R., Singh, V.P. and Prasad, S.M. 2015. Effect of salinity stress on plants and its tolerance strategies: a review. Environmental Science Pollution Research Institute, 22: 4056-75. https://doi.org/10.1007/s11356-014-3739-1

Praxedes, S.C., Damatta, F.M., Lacerda, C.F.D., Prisco, J.T. and Filho, E.G. 2014. Salt stress tolerance in cowpea is poorly related to the ability to cope with oxidative stress. Acta Botanica Croatica, 73: 51-62. https://doi.org/10.2478/botcro-2013-0010

SRDI (Soil Resources Development Institute). 2010. Saline Soils of Bangladesh. SRDI, Ministry of Agriculture, Dhaka, Bangladesh.

Thiam, M., Champion, A., Diouf, D. and Mame Ourèye, S.Y. 2013. $\mathrm{NaCl}$ effects on in vitro germination and growth of some Senegalese cowpea (Vigna unguiculata (L.) Walp.) cultivars. ISRN Biotechnology. Volume 2013, Article ID 382417, 11 pages. http://dx.doi.org/10.5402/2013/382417

Tsague, E.L., Kouam, E.B. and Tankou, C.M. 2017. Salinity tolerance at germination of some main cultivated cowpea (Vigna unguiculata) genotypes from Western Cameroon. Annals of Plant Sciences, 6: 1634-1639. https://doi.org/10.21746/aps.2017.06.002

Zhu, J.K. 2001. Plant salt tolerance. Trends in Plant Science, 6: 66-71. https://doi.org/10.1016/S1360-1385(00)01838-0 